\title{
USO DO ESPAÇO URBANO POR CONCESSIONÁRIAS DE SERVIÇOS DE TELECOMUNICAÇÕES
}

\author{
ADILSON ABREU DALLARI*
}

I - Considerações preliminares. II - Formas de uso de bens públicos. III - A legislação municipal sobre uso de bens públicos. IV - Servidões administrativas. $V$ - A legislação sobre concessões de serviços públicos. VI - A legislação federal sobre telecomunicaçōes. VII - Comentários à jurisprudência existente. VIII - Considerações doutrinárias. IX - Conclusões.

\section{I - Considerações preliminares}

É mansamente pacífico o entendimento no sentido de que a passagem de dutos e fiação por imóveis privados depende, normalmente, conforme as circunstâncias, ou de desapropriação da faixa correspondente, ou da instituição de servidão. Em qualquer caso, sempre haverá necessidade de indenizar o particular proprietário da área afetada, em razão dos danos que lhe forem acarretados pelo sacrifício parcial de seu direito de propriedade.

Questiona-se porém, a licitude ou a viabilidade da exigência de pagamento pela passagem de dutos ou fiação, feita por concessionário de serviço público, sobre ou sob área pública pertencente a pessoa jurídica distinta daquela outorgante da concessão.

$\mathrm{Na}$ mais resumida síntese, em tais situações, o que se alega, equivocadamente, é uma espécie de vocação natural das áreas públicas para a realização de serviços públicos, motivo pelo qual não se haveria de falar em pagamento pelo uso, mesmo que tais serviços fossem realizados por empresas privadas concessionárias, pois o serviço por elas explorado, em si mesmo, não deixa de ser serviço público, que acaba sendo remunerado mediante o pagamento de tarifas pelos consumidores, que outra

* Prof. Titular de Direito Administrativo da PUC/SP.

R. Dir. Adm., Rio de Janeiro, 223: 29-52, jan./mar. 2001 
coisa não são senão a mesma coletividade "dona" dos imóveis públicos afetados pelas redes.

A discussão desse assunto começa pela identificação do que deve ser entendido como "serviço público", o que se fará com a preciosa ajuda de CAIO TÁCITO, em estudo exatamente sobre o "Conceito de Serviço Público" (Temas de Direito Público - Estudos e Pareceres, Renovar, Rio de Janeiro, $1^{\circ}$ volume, 1997, págs. 637 a 642), do qual se extraíram as passagens que se seguem:

"Entre as mais árduas missões do jurista, no campo do Direito Administrativo, figura a de conceituar, adequadamente, o serviço público. Embora ocorra, fragmentariamente, a qualificação legal das atividades ou órgãos do Estado suscetíveis dessa designação não se torna fácil condensar, em síntese definidora, os elementos que o identifiquem, no tempo e no espaço".

"Costuma-se, ainda, opor, na caracterização do serviço público, a definição material ou funcional à concepção orgânica ou formal. A primeira tem em mira a atividade de interesse geral a que se destina o serviço; a segunda considera dominante o organismo administrativo que o desempenha.

Ao conceito jurídico do serviço público, como expressão típica de atividade estatal, poder-se-á, ainda, agregar a sua significação econômica, social, política ou fiscal, nem sempre coincidente com o sentido orgânico ou administrativo da expressão".

"Certamente a evolução moderna do Estrado exaltou de tal forma a sua participação na ordem social, que a essencialidade passou a abranger tanto os encargos tradicionais de garantias da ordem jurídica como as prestações administrativas que são emanações dos modernos direitos econômicos e sociais do homem, tão relevantes, na era da socialização do direito, como os direitos individuais o foram na instituição da ordem liberal".

"Temos, de uma parte, uma forma de ação geral e indivisível do serviço público, que atende diretamente a interesses coletivos indiscriminados (uti universi) e corresponde a uma atividade soberana e privativa do Estado.

De outra parte, ocorrem prestações de serviço que, embora genéricas quanto à sua disponibilidade, visam a satisfazer interesses que se podem individualizar entre determinadas pessoas, que as usufruem diretamente (uti singuli). Tais prestações administrativas não são privativas do Estado ratione materiae, não emanam de seu poder soberano, embora possam constituir monopólio estatal de lege".

São elementos integrantes do conceito a relevância social da atividade, quem a executa, o regime jurídico de execução, os consumidores atingidos e a forma de instituição. O objeto deste estudo é a prestação de serviços públicos "uti singuli", prestados a pessoas determinadas, cuja execução pode ser delegada a particulares.

Embora no decorrer da exposição sejam feitas referências a outros serviços análogos, o específico serviço público deflagrador do presente estudo é o de telefonia fixa, que é um serviço público federal.

Ou seja; não há um serviço público universal. Existem diferentes serviços públicos prestados sob diferentes regimes, por diferentes prestadores. No caso brasileiro, dada a estrutura federativa do Estado Nacional, cada serviço público será necessariamente jungido a uma específica entidade componente da federação, po- 
dendo afetar (e este é o ponto nodal da questão) direitos e interesses de outras entidades federadas.

Por força do disposto no art. 21, da Constituição Federal, compete à União:

"XI - explorar, diretamente ou mediante autorização, concessão ou permissão, os serviços de telecomunicações, nos termos da lei, que disporá sobre a organização dos serviços, a criação de um órgão regulador e outros aspectos institucionais;".

O serviço público de telefonia fixa, espécie do gênero serviços de telecomunicações, é, sem dúvida, um serviço público federal, mas teve sua execução delegada a empresas privadas, sob a forma de concessão, nos termos e condições estabelecidas pela Constituição Federal:

"Art. 175. Incumbe ao poder público, na forma da lei, diretamente ou sob regime de concessão ou permissão, sempre através de licitação, a prestação de serviços públicos.

Parágrafo único. A lei disporá sobre:

I - o regime das empresas concessionárias e permissionárias de serviços públicos, o caráter especial de seu contrato e de sua prorrogação, bem como as condições de caducidade, fiscalização e rescisão da concessão ou permissão;

II - os direitos dos usuários;

III - política tarifária;

IV - a obrigação de manter serviço adequado."

O concessionário não adquire a titularidade; apenas explora economicamente a prestação do serviço concedido, que continua sendo público e, como tal, sujeito a condicionamentos especiais e dotado de prerrogativas também especiais.

Para cumprir seu dever de prestar o serviço do qual é delegado, o concessionário necessita utilizar ou ocupar espaços físicos. Tal ocupação, em algumas situações, é excludente de qualquer outra, obrigando a que a empresa concessionária adquira tais espaços, por qualquer das formas civis ou por meio de desapropriação, pagando a justa indenização, seja lá quem for o proprietário do imóvel desapropriado.

Em outras situações, o uso feito pelo concessionário não é excludente; ou seja, pode conviver com outros usos. Ou, mais exatamente; o uso feito pelo concessionário não acarreta a necessidade de adquirir o imóvel, mas, sim, de apenas utilizá-lo. Quando a empresa concessionária necessita usar um imóvel alheio, ela pode obter o direito de fazê-lo tanto pelas formas civis, quanto por meio da instituição de servidão administrativa, pagando o valor correspondente aos danos materiais que o uso do imóvel alheio acarretar ao proprietário.

Quando esse direito de uso incide sobre imóvel particular, não há problema algum. O problema está no uso, pela empresa privada concessionária, para a prestação do serviço público concedido, de imóvel qualificado como bem público. Convém, portanto, agora, discorrer sobre o uso de bens públicos por pessoa física ou jurídica que não seja o titular de seu domínio.

O problema apontado não existe apenas na área das telecomunicações. $O$ que passa a ser dito, vale, em princípio, para qualquer outro serviço público concedido que apresente problemas análogos, como é o caso, por exemplo, do fornecimento de energia elétrica e de gás canalizado. Por essa razão, algumas referências legislativas, doutrinárias e, especialmente, jurisprudenciais, são relativas a tais serviços. 
Os bens públicos são normalmente utilizados pela Administração Pública detentora de sua titularidade, para a execução de seus serviços, ou são utilizados, de maneira geral, impessoal e indistinta, pela coletividade em geral, por todas as pessoas, em caráter não exclusivo, para fins de locomoção e recreação.

Quando determinada pessoa, física ou jurídica, necessita usar um bem público em caráter exclusivo, configura-se aquilo que a doutrina denomina de "uso especial de bem público", cujo regime jurídico é assim descrito por HELY LOPES MEIRELLES (Direito Administrativo Brasileiro, Malheiros, São Paulo, 25ª ed., 2.000, págs 474 e sgts.):

"Uso especial - uso especial é todo aquele que, por um título individual, a Administração atribui a determinada pessoa para fruir de um bem público com exclusividade, nas condições convencionadas".

"Ninguém tem direito natural a uso especial de bem público, mas qualquer indivíduo ou empresa pode obtê-lo mediante contrato ou ato unilateral da Administração, na forma autorizada por lei ou regulamento ou simplesmente consentida pela autoridade competente. Assim sendo, o uso especial do bem público será sempre uma utilização individual - uti singuli - a ser exercida privativamente pelo adquirente desse direito. O que tipifica o uso especial é a privatividade da utilização de um bem público, ou de parcela desse bem, pelo beneficiário do ato ou contrato, afastando a fruição geral e indiscriminada da coletividade ou do próprio Poder Público. Esse uso pode ser consentido gratuita ou remuneradamente, por tempo certo ou indeterminado, consoante o ato ou contrato administrativo que o autorizar, permitir ou conceder.

Uma vez titulado regularmente o uso especial, o particular passa a ter um direito subjetivo público ao seu exercício, oponível a terceiros e à própria Administração, nas condições estabelecidas ou convencionadas. A estabilidade ou precariedade desse uso assim como a retomada do bem público, com ou sem indenização ao particular, dependerão do título atributivo que o legitimar".

Os bens públicos, conforme acima referido, podem ser utilizados por terceiros por diversas formas já consagradas na legislação e na doutrina. Cada uma dessas formas tem características, condições e finalidades distintas.

Novamente recorremos ao magistério de HELY LOPES MEIRELLES (op. loc. cit.) para fornecer uma visão panorâmica e sintética, contendo apenas os elementos essenciais de cada uma dessa formas:

"Autorização de uso: autorização de uso é o ato unilateral, discricionário e precário pelo qual a Administração consente na prática de determinada atividade individual incidente sobre um bem público. Não tem forma nem requisitos especiais para sua efetivação, pois visa apenas a atividades transitórias e irrelevantes para o Poder Público, bastando que se consubstancie em ato escrito, revogável sumariamente a qualquer tempo e sem ônus para a Administração".

"Permissão de uso: permissão de uso é ato negocial, unilateral, discricionário e precário através do qual a Administração faculta ao particular a utilização individual de determinado bem público. Como ato negocial (TJSP, RJTJSP 124/202), 
pode ser com ou sem condições, gratuito ou remunerado, por tempo certo ou indeterminado, conforme estabelecido no termo próprio, mas sempre modificável e revogável unilateralmente pela Administração, quando o interesse público o exigir, dados sua natureza precária e o poder discricionário do permitente para consentir e retirar o uso especial do bem público. A revogação faz-se, em geral, sem indenização, salvo se em contrário se dispuser, pois a regra é a revogabilidade sem ônus para a Administração".

"Cessão de uso: cessão de uso é a transferência gratuita da posse de um bem público de uma entidade ou órgão para outro, a fim de que o cessionário o utilize nas condições estabelecidas no respectivo termo, por tempo certo ou indeterminado. É ato de colaboração entre repartiçōes públicas, em que aquela que tem bens desnecessários aos seus serviços cede o uso a outra que deles está precisando".

"Concessão de uso: concessão de uso é o contrato administrativo pelo qual o Poder Público atribui a utilização exclusiva de um bem de seu domínio a particular, para que o explore segundo sua destinação específica. $O$ que caracteriza a concessão de uso e a distingue dos demais institutos assemelhados - autorização e permissão de uso - é o caráter contratual e estável da outorga do uso do bem público ao particular, para que o utilize com exclusividade e nas condiçôes convencionadas com a Administração.

A concessão pode ser remunerada ou gratuita, por tempo certo ou indeterminado, mas deverá ser sempre precedida de autorização legal e, normalmente, de licitação para o contrato. Sua outorga não é nem discricionária nem precária, pois obedece a normas regulamentares e tem a estabilidade relativa dos contratos administrativos, gerando direitos individuais e subjetivos para o concessionário, nos termos do ajuste. Tal contrato confere ao titular da concessão de uso um direito pessoal de uso especial sobre o bem público, privativo e intransferível sem prévio consentimento da Administração, pois é realizado intuitu personae, embora admita fins lucrativos".

"Concessão de direito real de uso: a concessão de direito real de uso é o contrato pelo qual a Administração transfere o uso remunerado ou gratuito de terreno público a particular, como direito real resolúvel, para que dele se utilize em fins especificos de urbanização, industrialização, edificação, cultivo ou qualquer outra exploração de interesse social. É o conceito que se extrai do art. $7^{\circ}$ do Dec.-lei federal 271, de 28.2.67, que criou o instituto, entre nós.

A concessão de uso, como direito real, é transferível por ato inter vivos ou por sucessão legítima ou testamentária, a título gratuito ou remunerado, como os demais direitos reais sobre coisas alheias, com a só diferença de que o imóvel reverterá à Administração concedente se o concessionário ou seus sucessores não lhe derem o uso prometido ou o desviarem de sua finalidade, contratual".

"Enfiteuse ou aforamento - enfiteuse ou aforamento é o instituto civil que permite ao proprietário atribuir a outrem o domínio útil de imóvel, pagando a pessoa que o adquire (enfiteuta) ao senhoria direto uma pensão ou foro, anual, certo $e$ invariável (CC, art. 678). Consiste, pois, na transferência do domínio útil de imóvel público a posse, uso e gozo perpétuos da pessoa que irá utilizá-lo daí por diante".

Já tem entendido a jurisprudência (conf. RE $n^{\circ} 55.275$ STJ, Rel. Ministro DEMÓCRITO REINALDO, publicado na RDA 202/242) que, não obstante a Ad- 
ministração Pública possa ser locatária de imóvel particular, quando ela Administração outorga contratualmente o direito de uso remunerado e temporário de um imóvel público a pessoa privada, não se configura uma relação locatícia, regida pela legislação civil, mas, sim, uma concessão de uso, regida pelo direito administrativo.

De qualquer maneira, e isto é o que se quer destacar, em todos esses casos há uma relação negocial; não há compulsoriedade. Todas essas formas de uso especial de bem publico pressupõem um acordo de vontades. inclusive quanto ao preço a ser pago pelo uso.

Tanto faz que o outorgado seja pessoa física ou jurídica, de direito privado ou de direito público. Qualquer dessas formas pode servir para viabilizar o uso, por uma empresa concessionária de serviço público. de imóvel público necessário ao desenvolvimento dos serviços concedidos.

No caso especificamente em exame, da prestação de serviços de telefonia fixa, os problemas que estão surgindo e que suscitaram a formulação da consulta, se referem (não exclusivamente, mas em maior número) ao uso, pelas empresas concessionárias, do solo, do subsolo e do espaço aéreo de vias públicas urbanas, o que determina a necessidade de um exame dessas formas negociais de uso no âmbito da Administração Pública municipal.

\section{III - A legislação municipal sobre uso de bens públicos}

O Município, por força do disposto nos artigos $1^{\circ}, 18$ e 29 da Constituição Federal, é pessoa jurídica de direito público interno, integrante da federação brasileira, dotado de autonomia política, administrativa e financeira, regendo-se por sua respectiva Lei Orgânica e pela legislação própria que editar.

Cabe a cada Município dispor sobre o uso dos bens que integram seu patrimônio. Assim, cada problema surgido em cada específico Município, dependerá, para sua solução, do exame da legislação própria local. Não obstante, existem muitos pontos que são tratados nas diversas legislações municipais de maneira bastante assemelhada, permitindo que se teçam algumas considerações de ordem geral sobre o uso especial de bens públicos municipais.

Normalmente a Lei Orgânica do Município. em diversos artigos, que precisam ser examinados em seu conjunto, contempla os pontos principais referentes ao assunto. Inicialmente, é preciso verificar o que diz a LOM para se aferir se há, ou não, necessidade de autorização legislativa para a outorga.

Usualmente, as Leis Orgânicas restringem a obrigatoriedade de autorização da Câmara Municipal apenas à alienação de bens imóveis e, no tocante à sua gestão, apenas às figuras da concessão administrativa e de direito real de uso. Nos demais casos de mera gestão, normalmente, deixam ampla margem de liberdade ao Executivo.

O ponto fundamental da legislação local está na enumeração das competências do Prefeito Municipal. Na parte da lei Orgânica Municipal que disciplina esse assunto, cabe verificar quais os poderes conferidos ao Prefeito no tocante aos bens públicos municipais. 
As Leis Orgânicas costumam determinar que, para celebrar convênios ou acordos, atos bi ou multi laterais, é indispensável a autorização da Câmara, a qual não é exigida nos casos de outorga de simples permissões ou autorizações, atos unilaterais e precários, que não cerceiam a liberdade ou comprometem economicamente o Município.

Especificamente quanto à gestão dos bens municipais, como regra geral sua administração compete ao Prefeito, devendo ser respeitada a competência da Câmara quanto aqueles utilizados em seus serviços.

É normal que, na gestão dos bens municipais, seja dada competência ao Prefeito para atribuir o seu uso a terceiros, mediante concessão, permissão ou autorização, conforme o caso, o interesse público específico e as necessidades do outorgado. A enfiteuse ou aforamento praticamente não é utilizada.

A doutrina (conforme visto anteriormente) já traçou os pontos característicos, dessas diferentes modalidades, delineamento esse que, com alguma variação, costuma ser acatado pelas legislações locais.

Num primeiro momento, portanto, parece não haver grandes dificuldades na outorga do uso do solo, do subsolo e do espaço aéreo aos concessionários de serviços públicos federais, desde que se chegue a um acordo no tocante ao preço, mas é exatamente aqui que está o problema, dado que, tradicionalmente (por circunstâncias bastante conhecidas e que são irrelevantes para a solução da questão atual), esse uso nunca foi devidamente formalizado e nunca foi feito em caráter oneroso.

Agora, em face das circunstâncias vigentes, imediatamente aflora a pergunta: caso não se chegue a um acordo, o titular do bem público pode recusar-se a outorgar, por exemplo, uma concessão de uso ou permissão de uso? E a resposta é positiva: sim, pode, se não houver entendimento quanto às condições do ajuste, inclusive quanto ao preço.

Tal resposta deflagra imediatamente uma perplexidade: isso poderia inviabilizar a prestação de um serviço público concedido! Tal perplexidade, entretanto não existe, pois sendo público o serviço concedido, a empresa privada concessionária pode compelir o proprietário do bem púbico a possibilitar o seu uso, pela forma prevista na legislação brasileira exatamente para isso, qual seja a servidão administrativa, assunto sobre o qual se passa a discorrer.

\section{IV - Servidões administrativas}

Existe uma forma de utilização compulsória de bem público municipal por terceiro, desde que esse terceiro seja uma entidade federal ou estadual, ou empresa privada prestadora serviço público, mediante outorga da União ou do Estado. Trata-se da servidão administrativa, cuja instituição está prevista no art. 40 do Decreto Lei $n^{\circ} 3.365$, de 21/06/41, que dispõe sobre o processo da Desapropriação, o qual diz, em síntese, que os dispositivos dessa lei são aplicáveis, no que couber, à instituição de servidões administrativas.

Já tivemos ocasião de publicar estudo sobre o tema, no qual estabelecemos as diferenças entre a servidão administrativa e outros meios de intervenção estatal na 
propriedade alheia (as limitações administrativas e as desapropriações) e delineamos seus traços principais, estudo esse do qual nos permitimos transcrever o essencial:

"As limitações administrativas, enquanto tais, são sempre gratuitas. Representam a forma mais branda de atuação estatal no tocante à propriedade privada, pois nada retiram do proprietário.

No extremo oposto, temos o instituto da desapropriação, definido no Código Civil brasileiro como forma de extinção da propriedade privada. Com efeito, por meio da desapropriação o Estado faz desaparecer uma determinada propriedade privada, que é substituída por seu equivalente em dinheiro, e faz surgir, ao mesmo tempo, mas originariamente (sem que haja transferência), a propriedade pública.

A desapropriação é sempre onerosa. É a forma mais intensa de intervenção estatal na propriedade, pois retira totalmente o conteúdo do direito de propriedade.

Entre esses dois extremos estão as servidões administrativas, por meio das quais o Estado obtém o uso da propriedade privada sem retirá-la de seu proprietário, e se apresentam como medidas ora genéricas, ora específicas; ora gratuitas, ora onerosas.

Enquanto a desapropriação configura claramente uma obrigação de dar, inexistente nos outros meios de atuação estatal aqui referidos, o tipo de obrigação decorrente das limitações administrativas e das servidões administrativas não é tão evidente.

De maneira geral, pode-se dizer que das limitações decorre uma obrigação de não fazer, de abster-se, um "non facere"; enquanto das servidões deriva um dever de suportar que se faça, deixar fazer, um "pati".

"Cabe, por último, apenas registrar que as servidões administrativas admitem também uma separação entre indenizáveis e não indenizáveis. Ou seja, algumas são instituidas a título gratuito e outras a título oneroso, mas essa separação decorre não da essência ou da natureza de determinados tipos de servidão, mas, sim, das circunstâncias inerentes a cada caso concreto.

Em princípio, como ensina Bielsa, a servidão administrativa é indenizável, pois a proteção à propriedade alcança sua privação total ou parcial. A servidão, embora afete apenas o atributo da exclusividade, que deixa de existir, é uma privação parcial e, assim, em princípio indenizável.

Mas, intervém com rara argúcia Hely Lopes Meirelles, o que se indeniza no é a propriedade, mas o prejuizo eventualmente causado pelo uso público.

Em resumo, remanesce para o Estado o dever de indenizar somente quando e na medida em que a instituição de uma servidão administrativa causar um prejuizo ao titular da propriedade privada. Isto, entretanto, somente pode ser verificado em cada caso concreto".

(ADILSON ABREU DALLARI, "Servidões Administrativas", in RDP n' 5960, RT, São Paulo, pág. 90 e 91; 95 e 96).

Nada existe de novo ou inusitado na utilização do instituto jurídico da servidão administrativa como forma de obtenção do uso de imóveis alheios. O vetusto Código de Águas (Decreto $n^{\circ} 24.643$, de 10/04/34) já estabelecia, em seu art. 151, que o concessionário, para a exploração do serviço, tinha o direito de:

"c) estabelecer as servidões permanentes ou temporárias exigidas para as obras hidráulicas e para o transporte e distribuição de energia elétrica." 
Esse direito foi regulamentado pelo Decreto $\mathrm{n}^{\circ} 35.851$, de 16/07/54, que, não obstante cuide especificamente da transmissão e distribuição de energia elétrica, fornece um excelente quadro dos ônus e prerrogativas, de ambas as partes envolvidas, no tocante à instituição de servidão administrativa:

"ART. $1^{\circ}$ - As concessões para o aproveitamento industrial das quedas d'água, ou, de modo geral, para produção, transmissão e distribuição de energia elétrica, conferem aos seus titulares o direito de constituir as servidões administrativas permanentes ou temporárias, exigidas para o estabelecimento das respectivas linhas de transmissão e de distribuição.

ART. $2^{\circ}$ - A constituição da servidão a que se refere o artigo anterior, depende da expedição, pelo Poder Executivo, de decreto em que, para esse efeito, se reconheça a conveniência de estabelecê-la e se declarem de utilidade pública as áreas destinadas à passagem da linha.

$\S 1^{\circ}$ Para a fixação das áreas sujeitas ao ônus da servidão, a administração terá em vista, entre outros característicos, a tensão da linha, o número de circuitos e o tipo da construção.

$\S 2^{\circ}$ A servidão compreende o direito, atribuído ao concessionário, de praticar, na área por ela abrangida, todos os atos de construção, manutenção, conservação e inspeção das linhas de transmissão de energia elétrica e das linhas telegráficas e telefônicas auxiliares, sendo-lhe assegurado ainda o acesso à área da servidão, através do prédio serviente, desde que não haja outra via praticável.

ART. $3^{\circ}$ - Os proprietários das áreas atingidas pelo ônus limitarão o uso e gozo das mesmas ao que for compatível com a existência a servidão, abstendo-se, em consequiência, de praticar, dentro delas, quaisquer atos que a embaracem ou lhe causem dano, incluídos entre eles os de erguerem construções ou fazerem plantações de elevado porte.

$\S 1^{\circ} \mathrm{A}$ administração, ao expedir o decreto de servidão, poderá vedar que tais construções ou plantações se façam em uma faixa paralela à área da servidão, estabelecendo-lhe os respectivos limites.

$\S 2^{\circ}$ Aos concessionários é assegurado o direito de mandar podar ou cortar quaisquer árvores, que, dentro da área da servidão ou na faixa paralela à mesma, ameacem as linhas de transmissão ou distribuição.

ART. $4^{\circ}$ - Uma vez expedido o decreto de que trata o art. 1 , a constituição da servidão se realizará mediante escritura pública, em que o concessionário e os proprietários interessados estipulem, nos termos do mesmo decreto, a extensão e limites do ônus e os direitos e obrigações de ambas as partes.

$A R T .5^{\circ}$ - Os proprietários das áreas sujeitas à servidão têm direito à indenização correspondente à justa reparação dos prejuízos a eles causados pelo uso público das mesmas e pelas restrições estabelecidas ao seu gozo.

ART. $6^{\circ}$ - Os concessionários poderão promover, no caso de embaraço oposto pelos proprietários à constituição da servidão, ou ao respectivo exercício, as medidas judicias necessárias ao seu reconhecimento, cabendo-lhes também a faculdade de utilizar-se do processo da desapropriação, nos termos do art. 40 do Decreto-lei $n^{\circ}$ 3.365 , de 21 de junho de 1941." 
Conforme já foi acima referido, aplicam-se ao processo judicial de instituição de servidão, no que couber, as mesmas normas que disciplinam o processo da desapropriação. Em um e outro desses institutos jurídicos, sempre é possível atingir o resultado almejado de maneira amigável, desde que exista acordo quanto ao valor da indenização. Mas. da mesma forma que acontece na desapropriação, o cerne da maioria das ações judiciais versa sobre a fixação do valor da indenização.

Alguns excertos da jurisprudência são bastante ilustrativos. No primeiro deles, relatado pelo Eminente Desembargador MORAES SALLES, são enfocadas as diferenças fundamentais entre a desapropriação e a servidão:

"Como se sabe, a servidão administrativa distingue-se, nitidamente, da desapropriação (RTJ 67/294 e 52/284 e RDP 12/184).

Com efeito, a desapropriação retira a propriedade de alguém (particular ou entidade política menor) transferindo-a para o expropriante. Na servidão administrativa não se verifica a transmissão da propriedade, porque o ônus imposto pela Administração ao particular é meramente de uso público. Porque na desapropriação o particular é despojado do domínio, compensa-se o vazio econômico por ele sofrido mediante o pagamento de uma indenização. Recompõe-se seu patrimônio com a soma correspondente ao desfalque gerado pela desapropriação. Na servidão pública, entretanto, porque a propriedade permanece com o particular cujo bem foi afetado pela serventia, só serão indenizáveis os prejuizos acarretados pelo ônus.

Observa-se, portanto, que na desapropriação haverá sempre indenização; na servidão administrativa só se verificará ressarcimento quando houver prejuizo para o particular. Não havendo prejuízo, não terá lugar a indenização. Note-se, entretanto, que as restrições ao gozo do imóvel, impostas pela servidão ao proprietário, constituem prejuízos ao seu patrimônio, pelo que devem ser também indenizadas".

(TJSP - Ap. 113.013-2 - 9 . C. - j. 11.12.86 - rel. Des. Moraes Salles, in RT 616/86 e 87).

Em outro Acórdão, decidiu-se pela invalidação do laudo pericial, exatamente porque o perito estimou o valor da indenização devida pela instituição da servidão administrativa como se tratasse de uma desapropriação:

"De se concluir que o laudo pericial não agiu com acerto em fixar a indenização da faixa sob servidão como se a terra fosse desapropriada. Cumpria-lhe avaliar o prejuizo, a desvalorização (se houve) da construção do caminho que se sobrepõe aos dutos subterrâneos. $O$ expert não ofereceu elementos via dos quais se possa fixar a indenização. Desaceita a quantia que se encontrou, como indenização a um terreno desapropriado, impende encontrar o justo valor, a critério pericial".

(TJMG, Ap. 74.279-1-1 ${ }^{a}$. C. - j. 12.4.88- rel. Des. Paulo Tinôco, in RT 633/157)

Num terceiro Acórdão, o foco da controvérsia sobre a indenização devida incidia apenas sobre a área ocupada pelas torres de transmissão (não havendo questionamento quanto ao valor fixado para a faixa de passagem das linhas). Considerando que havia ocupação completa do terreno onde se situavam as torres, o perito estabeleceu a indenização pela instituição da servidão no valor correspondente ao da desapropriação. Tal valor foi reduzido pelo Acórdão: 
“A restrição sofrida pelos apelados, quanto à área em que instaladas as torres de transmissão de energia elétrica não corresponde à perda total dos direitos de propriedade, uma vez que de desapropriação não se cuida. Bem por isso, com razão a apelante, a sugerir o alto percentual, bem próximo do máximo, de $95 \%$ daquele fixado no laudo aceito. Esse valor é o que servirá de fundamento para o ressarcimento devido exclusivamente quanto às áreas das torres, como destacadas no laudo do assistente técnico (fls. 144), mantido embora o valor básico do laudo do perito judicial".

(TJSP, Ap. 199.280-2/2 - 13 ${ }^{\mathrm{a}}$ C. - j. 10.11 .92 - rel. Des. Wanderley Racy, in RT 692/88)

Conforme se pode notar, costuma-se estabelecer o valor da indenização pela servidão em um percentual aplicado sobre o valor do imóvel. Esse percentual é bastante variável, conforme demonstra RONALDO DE ALBUQUERQUE ("Desapropriação e Constituição de Servidão Administrativa", Atlas, 1987, págs. 132 e segts), mediante a transcrição parcial de vários Acórdãos.

O primeiro deles (TFR, Apelação Cível n³6.949) relatado pelo Ministro CARLOS VELLOSO, fixa o percentual em $50 \%$. Mas esse mesmo Eminente Ministro, quando ainda no mesmo TFR, em outro caso, na Apelação Cível $n^{\circ} 68.077$, considerando que se tratava de terrenos rurais distantes das zonas urbanas, fixou o percentual em $10 \%$.

Outro Acórdão (TFR, Apelação Cível n 73.655 , Relator Ministro ARMANDO ROLEMBERG), por se tratar de área bastante acidentada, utilizada para descanso e lazer, considera razoável o percentual de $20 \%$. Em outro Acórdão (TFR, Apelação Cível n $\mathrm{n}^{\circ}$ 82.333, Relator Ministro SEBASTIÃO ALVES DOS REIS), a onerosidade trazida ao imóvel pela servidão justifica a aplicação do índice de $40 \%$.

Como se nota, em diversos casos mais ou menos contemporâneos e até em Acórdãos proferidos pelo mesmo Relator, há uma grande diversidade de percentuais, determinados pelas circunstâncias do caso concreto e fixados por critério de razoabilidade.

Em face da proteção dada pela Constituição Federal à propriedade privada e diante da disciplina dada à fixação do valor da indenização pela legislação federal, cabe apenas dizer que, se não houver acordo entre as partes, caberá ao juiz estabelecer o valor da justa indenização.

Indenizar, etimologicamente, significa tornar indene, sem dano. Indenizar significa compor o dano, reparar integralmente o dano, na exata medida em que este se verificar e, obviamente, SE houver dano material, dado que lesão de direito sempre haverá, consistente na perda do direito de exclusividade sobre o imóvel afetado.

E quando será “ justa” a indenização? SÉRGIO FERRAZ (“A Justa Indenização na Desapropriação", RT, 1978, pág. 11) oferece alguns parâmetros:

"A idéia de justo, por mais variáveis que sejam as acepções de cunho filosófico incidentes sobre a construção desse conceito, necessariamente é informada de uma tônica de conformidade, congruência, proporção, equilíbrio, equivalência, correspondência ou paridade"

Não há, portanto, como se estabelecer, de maneira universal e segura, os critérios para a fixação da indenização devida pela instituição da servidão. No caso concreto 
sempre se haverá de considerar a efetiva restrição acarretada ao imóvel, podendo ocorrer que isso até mesmo não aconteça (ou aconteça em grau mínimo), sendo também relevantes os proveitos que poderão advir da execução do serviço para o próprio titular do bem afetado, inclusive a utilização que ele possa vir a fazer dos dutos e postes instalados.

O fato é que a possibilidade da instituição de servidões administrativas também está expressamente prevista na legislação que disciplina os serviços de telecomunicações. O art. 100, da Lei $n^{\circ}$ 9.472/97 - a chamada Lei Geral de Telecomunicações, dispõe nestes termos:

"Art. 100 - Poderá ser declarada a utilidade pública, para fins de desapropriação ou instituição de servidão, de bens imóveis ou móveis, necessários à execução do serviço, cabendo à concessionária a implementação da medida e o pagamento da indenização e das demais despesas envolvidas".

Dispositivo correlato figura na recente legislação federal que trata das concessões de serviços de energia elétrica. A Lei $n^{\circ} 9.074$, de 07/07/95, em seu art. 10 (com a redação dada pela Lei $n^{\circ} 9.648$, de $27 / 05 / 98$ ), também cuida da instituição de servidões administrativas:

"ART. 10 - Cabe à Agência Nacional de Energia Elétrica - ANEEL, declarar a utilidade pública, para fins de desapropriação ou instituição de servidão administrativa, das áreas necessárias à implantação de instalações de concessionários, permissionários e autorizados de energia elétrica."

A lei geral de concessões de serviços públicos, Lei $\mathbf{n}^{\circ}$ 8.987, de 13/02/1995, que "Dispõe sobre o Regime de Concessão e Permissão da Prestação de Serviços Públicos previsto no art. 175 da Constituição Federal, e dá outras providências", não deixou esse assunto de lado, tendo incluído a viabilização da instituição de servidões como um encargo do concedente, paralelamente às desapropriações necessárias à execução dos serviços concedidos:

"ART. 29 - Incumbe ao poder concedente:

VIII - declarar de utilidade pública os bens necessários à execução do serviço ou obra pública, promovendo as desapropriações, diretamente ou mediante outorga de poderes à concessionária, caso em que será desta a responsabilidade pelas indenizações cabíveis;

IX - declarar de necessidade ou utilidade pública, para fins de instituição de servidão administrativa, os bens necessários à execução de serviço ou obra pública, promovendo-a diretamente ou mediante outorga de poderes à concessionária, caso em que será desta a responsabilidade pelas indenizações cabíveis;"

Em síntese, não existe possibilidade jurídica de o Município (ou qualquer outra entidade pública estadual, ou qualquer delegatário de serviço público estadual ou municipal) impedir a instalação e funcionamento de um serviço público federal concedido negando autorização para a instalação de dutos, postes e fiação. Se não se chegar a um entendimento quanto ao uso do solo, do subsolo e do espaço aéreo municipal (ou estadual), sempre haverá possibilidade de se recorrer à via judicial para que isso seja feito de maneira coercitiva. 


\section{$\mathrm{V}$ - A legislação sobre concessões de serviços públicos}

Para os fins do presente estudo, cabe agora examinar a questão da repercussão dos ônus e encargos econômicos e financeiros decorrentes do uso remunerado de imóveis de terceiros para a instalação de dutos e fiação.

A concessão de serviço público é um contrato administrativo, e como tal, está sujeita à aplicação subsidiária dos princípios e das normas previstas na $\mathrm{Li}^{\circ}{ }^{\circ}$ 8.666/93, que (além das licitações) cuida dos contratos administrativos em geral, estabelecendo o direito à manutenção do equilíbrio econômico-financeiro do contrato.

A expressão define a necessária relação de igualdade entre as partes celebrantes de um contrato administrativo no que tange especificamente às cláusulas econômicas. Estas não podem ser alteradas unilateralmente, por expressa proibição constante do $\S 1^{\circ}$, do art. 58 , da Lei $n^{\circ} 8.666 / 93$

Nas demais, ou seja, naquelas que ajustam a forma e o conteúdo do objeto pactuado, as chamadas cláusulas regulamentares, a Administração Pública atua segundo uma posição sobranceira em relação ao particular, podendo promover alterações unilaterais no ajuste ao sabor único e exclusivo do interesse público que representa. Para fazer valê-lo, ela pode e deve se socorrer de todos os instrumentos previstos em lei, sem que o particular possa a isso se contrapor.

Isso não significa, entretanto, que os interesses do contratado não estejam resguardados, pois se assim fosse a Administração jamais encontraria quem com ela quisesse contratar. Os propósitos mercantis do particular contratado formam a esfera intangível e imutável do ajuste, cabendo-lhe integral proteção no que tange à fórmula financeira inicialmente prevista para a relação. A remuneração originalmente projetada para o negócio até seu término deve se manter, ainda que a Administração, ao influxo da necessidade pública, promova alterações nas prestações avençadas.

Assim, a lei disciplina as garantias do particular à manutenção do equilíbrio econômico-financeiro do ajuste, a ele se referindo em inúmeras passagens, como se verifica em seus artigos $57, \S 1^{\circ}, 58, \S \S 1^{\circ}$ e $2^{\circ}$, e $65, \mathrm{II}, d, \S \S 5^{\circ}$ e $6^{\circ}$, dentre outros dispositivos cujos termos são menos expressos sobre a questão. Importa, em razão disso, que a Administração sempre tem o dever de ressarcir integralmente os agravos econômicos que causar ao contratado.

Ou seja, cada parte há de se responsabilizar por aquilo a que se obrigou. Se o particular assumiu o encargo de executar o contrato por determinado preço, salvo situações excepcionais previstas na lei, deve honrar esse preço. Nesse preço estão seus custos e seus lucros. Mas ele não pode ser obrigado a honrar esse preço por algo diferente daquilo que ele se comprometeu a executar, ou se, no curso da vigência do contrato, surgirem fatores imprevistos e imprevisíveis que venham a onerar significativamente os custos.

Diga-se de uma vez: o particular somente poderá experimentar um prejuízo SE decorrente de SUA incúria, de SUA incapacidade, de SUA inabilitação para fazer o que se propôs, enfim, de SUA imprevidência, e NUNCA por algo atribuível à Administração concedente ou, ainda, o outros órgãos ou entidades do Poder Público, mesmo que de outra esfera de governo. 
A Lei $n^{\circ} 8.987$, de 13/02/95, que disciplina as concessões de serviços públicos, cuida da manutenção do equilíbrio econômico-financeiro do contrato ao dispor sobre as tarifas, em seu art. $9^{\circ}$ :

"ART. $9^{\circ}$ - A tarifa do serviço público concedido será fixada pelo prȩ̧o da proposta vencedora da licitação e preservada pelas regras de revisão previstas nesta Lei, no edital e no contrato.

$\S 1^{\circ} \mathrm{A}$ tarifa não será subordinada à legislação específica anterior e somente nos casos expressamente previstos em lei, sua cobrança poderá ser condicionada à existência de serviço público alternativo e gratuito para o usuário.( redação dada pela Lei $\mathrm{n}^{\circ} 9.648$, de $27 / 05 / 1998$ ).

$\S 2^{\circ}$ Os contratos poderão prever mecanismos de revisão das tarifas, a fim de manter-se o equilíbrio econômico-financeiro.

$\S 3^{\circ}$ Ressalvados os impostos sobre a renda, a criação, alteração ou extinção de quaisquer tributos ou encargos legais, após a apresentação da proposta, quando comprovado seu impacto, implicará a revisão da tarifa, para mais ou para menos, conforme o caso.

$\S 4^{\circ} \mathrm{Em}$ havendo alteração unilateral do contrato que afete o seu inicial equilíbrio econômico-financeiro, o poder concedente deverá restabelecê-lo, concomitantemente à alteração."

Esta alteração unilateral do contrato, mencionada no $\S 4^{\circ}$, tanto pode decorrer de uma específica alteração das cláusulas de serviço, promovida pelo concedente, como pode, também, ser decorrente de alterações das condições de execução do serviço acarretadas por fatos da natureza ou decisões governamentais estranhas ao contrato de concessão, adotadas pela mesma ou por outras esferas de governo, mas com impacto sobre o equilíbrio contratual.

Essa questão foi objeto de percuciente observação feita por MARÇAL JUSTEN FILHO ( "Concessões de Serviços Públicos", Dialética, São Paulo, 1997, pág. 145 e 146) que merece transcrição:

"Reconhece-se que a equação econômico-financeira é intangível, na acepção de que, uma vez aperfeiçoada, não pode ser infringida. A manutenção do equilíbrio econômico-financeiro consiste na impossibilidade de alterar apenas um dos ângulos da equação. Não é possivel alterar, quantitativa ou qualitativamente, apenas o âmbito dos encargos ou tão-somente o ângulo das retribuiçôes. Se forem adicionados encargos, rompe-se o equilíbrio, a não ser que também se ampliem as retribuições. Idêntico raciocínio se aplica em caso de redução dos encargos, o que acarretará a necessidade de redução das retribuições. Em sintese, a manutenção do equilibrio econômico-financeiro corresponde a uma espécie de magnetização dos ângulos ativo e passivo do conteúdo da relação jurídica: à alteração de um ângulo deve corresponder uma alteração equivalente e correspondente no outro ângulo".

Disso se infere que tanto o aumento de encargos, quanto o aumento de receita podem acarretar a necessidade de recomposição do equilíbrio contratual.

No tocante à concessão de serviços públicos de telefonia fixa, se ficar comprovado que o ônus decorrente da remuneração pelo uso dos imóveis de terceiros não estava inserido na composição inicial dos custos, configurando-se como um ônus adicional imprevisível e inevitável, certamente haverá necessidade de recompor o equilíbrio contratual, inclusive por meio de compensação no valor da tarifa. 
Mas há uma outra faceta que merece destaque. Situações existem nas quais a exigência de remuneração pelo uso do imóvel é feita por concessionário de outro serviço concedido (como, por exemplo, a operação de rodovias), o qual irá experimentar uma receita adicional, diversa da tarifa cobrada pela execução do serviço, que, em princípio precisa ser compensada, conforme previsto no art. 11 da Lei $\mathrm{n}^{\circ}$ 8.987/95:

"ART. 11 - No atendimento às peculiaridades de cada serviço público, poderá o poder concedente prever, em favor da concessionária, no edital de licitação, a possibilidade de outras fontes provenientes de receitas alternativas, complementares, acessórias ou de projetos associados, com ou sem exclusividade, com vistas a favorecer a modicidade das tarifas, observado o disposto no art. 17 desta Lei.

Parágrafo único. As fontes de receita previstas neste artigo serão obrigatoriamente consideradas para a aferição do inicial equilíbrio econômico-financeiro do contrato."

Também se coloca essa questão da compensação nos casos de compartilhamento remunerado da infra-estrutura, nos quais será necessário verificar qual o ônus efetivamente acarretado para cada um dos concessionários envolvidos, em função das remunerações pagas e recebidas.

Em qualquer hipótese, porém, sempre será necessário observar a legislação federal sobre telecomunicações, que passa a ser examinada.

\section{VI - A legislação federal sobre telecomunicações}

É oportuno repetir que, por força do disposto no art. 21, da Constituição Federal, compete à União:

"XI - explorar, diretamente ou mediante autorização, concessão ou permissão, os serviços de telecomunicações, nos termos da lei, que disporá sobre a organização dos serviços, a criação de um órgão regulador e outros aspectos institucionais;".

Concessão e permissão de serviços públicos (que não se confundem com concessão e permissão de uso de bens públicos) são formas tradicionais de outorga a particulares do direito de explorar serviços públicos. A grande novidade trazida ao inciso supra transcrito, pela redação que the foi dada pela Emenda Constitucional $\mathrm{n}^{\circ} 8$, de $15 / 08 / 95$, é a previsão da figura da "autorização". Sobre este específico ponto, convém destacar a abordagem doutrinária que esclarece tratar-se de um terceiro instituto jurídico com a mesma designação de outros já conhecidos e descreve suas características principais:

"Doutrinariamente as autorizações sempre foram consideradas modalidades unilaterais de anuência estatal com a prática de certas atividades ou com a ocupação de bens públicos por particulares.

Não obstante, o legislador constitucional empregou exatamente este mesmọ nomen juris para designar uma modalidade de delegação unilateral de serviços públicos, ao lado das duas outras modalidades contratuais, a concessão e a permissão.

Como modalidade unilateral de transferência administrativa essas autorizações de assento constitucional existem exclusivamente para emprego pela União e volta- 
das especificamente à prestação dos serviços públicos contemplados no art. 21 , incisos XI: telecomunicaçōes e XII: a) radiofusão sonora, b) energia elétrica, c) navegação aérea, aerospacial e infra-estrutura aeroportuária, d) transporte ferroviário e aquaviário entre portos brasileiros e fronteiras nacionais, ou que transponham os limites de Estado ou Território, e) os serviços de transporte rodoviário interestadual e internacional de passageiros, e, f) os portos marítimos, fluviais e lacustres.

Inexistem, portanto, autorizações como instrumento de prestação de serviços públicos nos Estados e Municípios, pois o art. 175 da Constituição Federal só admitiu os dois regimes contratuais a que se refere: a concessão e a permissão".

DIOGO DE FIGUEIREDO MOREIRA NETO, "Mutações do Direito Administrativo", Renovar, 2000, págs. 127, 137 e 138.

A transcrição acima se justifica pelo fato de que, na área de telecomunicações, alguns serviços (como a instalação de redes de fibra ótica) são outorgados a particulares na modalidade de "autorização", mas essa específica autorização prevista na Constituição Federal, e não a autorização mencionada na LOM, que serve a outras finalidades. É importante mencionar essa possibilidade em razão de problemas que podem surgir no compartilhamento da infraestrutura, conforme será visto logo mais adiante.

A legislação federal sobre telecomunicações é bastante complexa e para entendê-la é preciso percorrer um longo caminho, que começa pela Lei $\mathrm{n}^{\circ} 9.472$ de 16/06/97, Lei Geral de Telecomunicações, podendo-se ir diretamente a seus artigos 62, 63 e 64, onde se encontra uma (parcial) classificação dos serviços de telecomunicações:

"Art. 62 - Quanto à abrangência dos interesses a que atendem, os serviços de telecomunicações classificam-se em serviços de interesse coletivo e serviços de interesse restrito.

Parágrafo único. Os serviços de interesse restrito estarão sujeitos aos condicionamentos necessários para que sua exploração não prejudique o interesse coletivo.

Art.63 - Quanto ao regime jurídico de sua prestação, os serviços de telecomunicações classificam-se em públicos e privados.

Parágrafo único. Serviço de telecomunicações em regime público é o prestado mediante concessão ou permissão, com atribuição a sua prestadora de obrigações de universalização e de continuidade.

ART.64 - Comportarão prestação no regime público as modalidades de serviço de telecomunicações de interesse coletivo, cuja existência, universalização e continuidade a própria União comprometa-se a assegurar.

Parágrafo único. Incluem-se neste caso as diversas modalidades do serviço telefônico fixo comutado, de qualquer âmbito, destinado ao uso do público em geral".

Os serviços de telefonia fixa em exame são prestados sob regime público e são de interesse coletivo, sendo outorgados mediante concessão.

A instalação de redes de suporte aos serviços de telecomunicações se enquadra como serviço de interesse coletivo, prestado sob regime privado, daí sua outorga mediante simples autorização, conforme previsto no art. 131 da mesma Lei.

Todos os serviços de interesse coletivo, inclusive aqueles prestados em regime privado, estão sujeitos à regra do art. 73 da Lei Geral de Telecomunicações: 
"Art. 73 - As prestadoras de serviços de telecomunicações de interesse coletivo terão direito à utilização de postes, dutos, condutos e servidões pertencentes ou controlados por prestadora de serviços de telecomunicaçōes ou de outros serviços de interesse público, de forma não discriminatória e a preços e condições justos e razoáveis.

Parágrafo único. Caberá ao órgão regulador do cessionário dos meios a serem utilizados definir as condições para adequado atendimento do disposto no "caput".

Isso significa que a outorga do direito de uso de imóvel alheio feita a uma empresa (inclusive por meio da instituição de servidão administrativa) aproveita a todo o sistema, ou seja, a todas as outras empresas que explorem outros serviços de telecomunicações de interesse coletivo, no limite das possibilidades físicas e nos termos das normas pertinentes.

Cabe destacar que qualquer empresa, concessionária, permissionária ou autorizatária de serviços de telecomunicações, não está imune à observância das normas locais no tocante a suas instalações físicas:

"Art. 74 - A concessão, permissão ou autorização de serviço de telecomunicações não isenta a prestadora do atendimento às normas de engenharia e às leis municipais, estaduais ou do Distrito Federal relativas à construção civil e à instalação de cabos e equipamentos em logradouros públicos".

Fica perfeitamente claro que a lei federal não autoriza (nem poderia autorizar) a simples desconsideração das competências que a própria Constituição Federal outorga ao Município. A instalação de cabos e equipamentos deve ser feita em harmonia com os interesses municipais, devendo, sempre que possível, haver um entendimento, um diálogo, uma negociação entre o concessionário e a autoridade local, sendo certo que nesse relacionamento o concessionário sempre deverá ter respaldo da autoridade federal concedente (inclusive para a instituição de servidão administrativa, se necessário), pois, conforme consta do art. 64, acima transcrito, a União se compromete a assegurar a viabilidade, a universalidade e a continuidade do serviço, nos termos do que consta dos arts. 79 e 80 :

"ART.79 - A Agência regulará as obrigações de universalização e de continuidade atribuídas às prestadoras de serviço no regime público.

$\S 1^{\circ}$ Obrigações de universalização são as que objetivam possibilitar o acesso de qualquer pessoa ou instituição de interesse público a serviço de telecomunicações, independentemente de sua localização e condição sócio-econômica, bem como as destinadas a permitir a utilização das telecomunicações em serviços essenciais de interesse público.

$\S 2^{\circ}$ Obrigações de continuidade são as que objetivam possibilitar aos usuários dos serviços sua fruição de forma ininterrupta, sem paralisações injustificadas, devendo os serviços estar à disposição dos usuários, em condições adequadas de uso.

ART.80 - As obrigações de universalização serão objeto de metas periódicas, conforme plano específico elaborado pela Agéncia e aprovado pelo Poder Executivo, que deverá referir-se, entre outros aspectos, à disponibilidade de instalações de uso coletivo ou individual, ao atendimento de deficientes físicos, de instituições de caráter público ou social, bem como de áreass rurais ou de urbanização precária e de regiões remotas." 
Evidentemente, as metas acima referidas não poderão ser atingidas se não houver possibilidade concreta de instalação das redes e equipamentos. Além disso, os aspectos sociais do serviço, sua relevância social, os ônus decorrentes de benefícios proporcionados à coletividade, devem ser considerados tanto na negociação com a autoridade municipal, acima referida, quanto na eventual fixação judicial do valor da indenização devida pela instituição de servidão administrativa.

O certo é que, conforme consta do art. $2^{\circ}$ do "Plano Geral de Outorgas", aprovado pelo Decreto $\mathrm{n}^{\circ} 2.534$, de $03 / 04 / 98$, as empresas prestadoras do serviço telefônico fixo comutado têm direito à "implantação, expansão e operação dos troncos, redes e centrais de comutação necessários à sua execução", devendo a União zelar pela eficácia concreta desse direito.

É um poder/dever da União assegurar a interconexão e o funcionamento do serviço como um todo, abrangendo tanto os segmentos de interesse coletivo quanto restrito, prestados em regime público ou privado, como é o caso das redes de suporte.

A implantação e o funcionamento de redes de telecomunicações destinadas a dar suporte à prestação de serviços de interesse coletivo, no regime público ou privado, está prevista no art. 145 e seguintes da Lei Geral de Telecomunicações, merecendo destaque, o disposto no art. 147 :

"Art. $147-E$ obrigatória a interconexão às redes de telecomunicações a que se refere o art. 145 desta Lei, solicitada por prestadora de serviço no regime privado, nos termos da regulamentação".

O que se pretende reafirmar é a utilização geral das redes de suporte, ou seja, que o empreendimento feito por uma empresa aproveita a todo o sistema de telecomunicações. Ou seja: o interesse por determinada utilização de um específico trecho de imóvel municipal ou estadual, transcende o interesse da empresa concessionária, sendo efetivamente de interesse de todo o sistema.

Para garantir essa possibilidade de utilização geral, a legislação em exame atribuiu à ANATEL competência para estabelecer normas regulamentares que assegurem a compatibilização e a harmonia entre os serviços explorados por diferentes prestadoras:

"Art. 150 - A implantação, o funcionamento e a interconexão das redes obedecerão à regulamentação editada pela Agência, assegurando a compatibilidade das redes das diferentes prestadoras, visando à sua harmonização em âmbito nacional e internacional".

Não cabe à Prefeitura (ou ao Estado) interferir, de qualquer forma, nos equipamentos e no serviço de transmissão, sendo, portanto, evidentemente descabida qualquer taxa pelo exercício do poder de polícia quanto a isso, mesmo que instituída com o "nome" de preço público. Cabe ao Município, sim, cuidar dos aspectos urbanísticos das instalações, para que a cidade não seja desfigurada nem haja riscos ou inconvenientes para os munícipes, mas também não pode cobrar taxa de polícia quanto a isso, por força da imunidade conferida pelo $\S 3^{\circ}$, do art. 155 , da Constituição Federal, que será objeto de exame mais adiante.

Também não pode a Prefeitura impedir o compartilhamento da rede não só por outras empresas prestadoras de serviços de telecomunicações, como também, eventualmente, por outras empresas que explorem serviços de energia elétrica e transporte 
de combustíveis, evidentemente, na medida em que isso for compatível com permissão de uso por ela outorgada, ou com os termos e limites de servidão administrativa que tenha sido instituída, e com as normas federais que regem a matéria.

Sobre esse assunto, o Governo Federal editou a Resolução Conjunta $n^{\circ} 001$, de 24 de novembro de 1999, firmada pela Agência Nacional de Energia Elétrica (ANEEL), pela Agência Nacional de Telecomunicações (ANATEL) e pela Agência Nacional do Petróleo (ANP), que aprova o Regulamento Conjunto para Compartilhamento de Infra-Estrutura entre os Setores de Energia Elétrica, Telecomunicações e Petróleo, do qual merece destaque o art. $4^{\circ}$ :

"Art. $4^{\circ}$. O agente que explora serviços públicos de energia elétrica, serviços de telecomunicações de interesse coletivo ou serviços de transporte dutoviário de petróleo, seus derivados e gás natural, tem direito a compartilhar infra-estrutura de outro agente de qualquer destes setores, de forma não discriminatória e a preços e condições justos e razoáveis, na forma deste Regulamento".

$\mathrm{O}$ art. $7^{\circ}$ desse Regulamento Conjunto, ao discriminar as infra-estruturas e os correspondentes itens passíveis de compartilhamento, menciona, expressamente, "dutos, condutos, postes e torres".

Em resumo, a matéria está exaustivamente tratada na legislação federal, cabendo ao Município preocupar-se exclusivamente com o que interferir na disciplina do uso do solo, do subsolo e do espaço aéreo urbanos e, muito especialmente, com os bens que integram seu patrimônio imobiliário, inclusive vias e logradouros públicos, podendo, sim, condicionar seu uso ao pagamento do preço correspondente, não obstante os revezes que tem suportado na esfera judicial, que passam a ser examinados.

\section{VII — Comentários à jurisprudência existente}

Um considerável número de Municípios, por lei ou decreto, com os mais variáveis conteúdos e fundamentos, instituiu a exigência de pagamento, por parte da concessionária de serviço federal ou estadual, pelo uso do subsolo, do solo e do espaço aéreo, ocupado por dutos, postes e fiação. A quase totalidade se deu mal; quase todas as exigências municipais foram suspensas liminarmente ou anuladas por decisões judiciais.

Não é o caso de se proceder a um exame detalhado de cada um ou de alguns desses casos. Para os fins deste estudo, basta destacar os aspectos mais relevantes que foram considerados nas decisões judiciais.

Alguns Municípios instituíram o IPTU, correspondente à área física ocupada pelos postes, ou também pela área dos dutos ou da projeção do espaço aéreo. Outros, preferiram cobrar taxa pelo exercício do poder de polícia, invocando a necessidade de disciplinar o uso do espaço urbano, inclusive sob o aspecto ambiental. Enfim, muitos instituíram um tributo incidente, direta ou indiretamente, sobre os serviços concedidos.

Em tais casos a cobrança foi fulminada pelo Poder Judiciário com base no disposto no $\S 3^{\circ}$, do art. 155 da Constituição Federal (com a redação dada pela Emenda Constitucional $n^{\circ} 3$ ), cuja redação é a seguinte: 
“§ $3 .^{\circ}$ À exceção dos impostos de que tratam o inciso II do caput deste artigo e o art. 153, I e II, nenhum outro tributo poderá incidir sobre operações relativas a energia elétrica, serviços de telecomunicações, derivados de petróleo, combustíveis e minerais do País."

Efetivamente, por força desse dispositivo, com exceção de ICMS, e dos tributos incidentes sobre importação e exportação, nenhum outro tributo pode recair sobre os mencionados serviços.

Note-se, porém, que o dispositivo não tem a dimensão que lhe tem sido dada, pois ele não impede a cobrança de tributos incidentes sobre a empresa concessionária (como, por exemplo, a taxa de água e esgoto), nem, muitíssimo menos, impede a cobrança de qualquer outra coisa que não seja um tributo.

Diante disso, alguns Municípios instituíram preços públicos pelo uso dos bens imóveis urbanos, mas, na disciplina da matéria, deram à cobrança todas as características de verdadeiro tributo, inclusive com alíquotas e bases de cálculo. Em tais casos, apenas o nome dado ao encargo financeiro era "preço público", mas a substância era de verdadeiro tributo, justificando-se, assim, a fulminação judicial.

Outro Municípios, entretanto, instituíram verdadeiros preços públicos, com base nas respectivas Leis Orgânicas, mas, mesmo assim, tiveram a pretensão repelida na via judicial, com fundamento no disposto no Decreto federal $n^{\circ} 84.398$, de 16/01/1980, que "Dispõe sobre a Ocupação de Faixas de Domínio de Rodovias e de Terrenos de Domínio Público e a Travessia de Hidrovias, Rodovias e Ferrovias, por Linhas de Transmissão, Subtransmissão e Distribuição de Energia Elétrica, e dá outras Providências".

$\mathrm{O}$ art. $1^{\circ}$ desse Decreto, com a redação que the foi dada pelo Decreto 86.859 , de 19/01/1982, assim dispõe:

"ART. $1^{\circ}-A$ ocupação de faixas de domínio de rodovias, ferrovias e de terrenos de domínio público, e a travessia de hidrovias, rodovias, ferrovias, oleodutos e linhas de transmissão de energia elétrica de outros concessionários, por linhas de transmissão, subtransmissão e distribuição de energia elétrica de concessionários de serviços públicos de energia elétrica, serão autorizadas pelo órgão público federal, estadual ou municipal ou entidade competente, sob cuja jurisdição estiver a área a ser ocupada ou atravessada.

Parágrafo único. Para os fins do disposto neste artigo, será considerada entidade competente a pessoa física ou jurídica que, em razão de concessão, autorização ou permissão, for titular dos direitos relativos à via de transporte, duto ou linha a ser atravessada, ou a ter a respectiva faixa de domínio ocupada."

Até aqui, nada existe que mereça maiores comentários. O problema está no art. $2^{\circ}$, desenganadamente inconstitucional:

"ART. $2^{\circ}$ - Atendidas as exigências legais e regulamentares referentes aos respectivos projetos, as autorizações serão por prazo indeterminado e sem ônus para os concessionários de serviços públicos de energia elétrica." (destacamos)

Salta aos olhos que não cabe à União dispor sobre o uso de bens públicos municipais, e muito menos por meio de simples decreto. Nem se diga que, no caso, a mencionada norma estaria apenas disciplinando um serviço público federal. Se assim for entendido, será forçoso concluir que a gratuidade aí afirmada poderia 
estender-se também sobre bens públicos de particulares, pois o serviço continuaria sendo público federal.

Para sustentar a constitucionalidade desse dispositivo, argumentou-se com o vetusto entendimento (já afastado pela melhor doutrina e jurisprudência) de que os bens públicos pertencem à coletividade, aos cidadãos, e não a esta ou aquela específica pessoa jurídica de direito público.

Obviamente, tal entendimento, já repudiado pelos Tribunais, não tem como sustentar-se à luz dos princípios da autonomia municipal e da legalidade.

Com efeito, a autonomia municipal compreende a titularidade de todos os bens municipais e especialmente a plena liberdade, sem qualquer turbação não expressamente fundada na Constituição Federal, de sua administração. Além disso, decreto não é lei; é mero ato administrativo, de conteúdo normativo, dispondo sobre meios e modos de execução de alguma específica lei (que no caso não existe) e dirigido aos subordinados de seu signatário (coisa que o Município não é, com relação ao Presidente da República).

Esse específico dispositivo foi enfocado em artigo publicado na Revista Literária do Direito (março/abril 2.000, pág. 29) pelo respeitado mestre de Direito Constitucional da Universidade Federal de Sergipe, CARLOS AUGUSTO ALCÂNTARA MACHADO, que, após cuidadosa análise e fundamentação, chegou às seguintes conclusões:

“a) $O$ uso dos bens públicos, em especial o do solo urbano, por expressa disposição legal, pode ser gratuito ou oneroso, não havendo nenhum óbice para, mediante lei, ser fixada retribuição pela utilização uti singuli do respectivo bem.

b) O município, em face de sua autonomia como ente integrante da Federação brasileira, poderá fixar, obedecendo ao princípio da legalidade, retribuição pelo uso do solo urbano, que não terá natureza tributária.

c) A competência privativa da União para legislar e dispor sobre concessão do serviço público de energia elétrica não tem abrangência de interferir na autonomia municipal, pois se trata de prerrogativa de raiz constitucional e inerente à estrutura do Estado brasileiro.

d) $\mathrm{O}$ artigo $2^{\circ}$ do Decreto federal $n^{\circ} 84.398 / 80$, na parte que autoriza o uso do solo sem ônus, não foi recepcionado pela atual ordem constitucional."

É evidente que o Município não pode proibir, impedir ou prejudicar o funcionamento de um serviço público federal. Mas é também verdade que a execução de serviço público federal não pode servir de pretexto, nem tem força suficiente, para destroçar o princípio constitucional da autonomia municipal e, por extensão, o próprio princípio federativo, que integra o chamado cerne fixo da Constituição, não podendo ser abolido nem mesmo por Emenda Constitucional (confira-se, CF art. 60 , $\left.\S 4^{\circ}, I\right)$.

O Município pode ser até mesmo compelido judicialmente a ceder o domínio ou o uso de seus bens para viabilizar o funcionamento de um serviço publico federal, por meio de desapropriação ou constituição de servidão administrativa, mas não gratuitamente. 
Hoje em dia (salvo alguma absoluta exceção) não mais se sustenta que os bens públicos possam ser havidos como "res nulius" (coisa de ninguém) ou "res comunis omni" (coisa pertencente á coletividade, na linguagem atual, bem difuso).

A melhor doutrina do direito administrativo é unânime em afirmar que os bens públicos são de propriedade ou domínio das pessoas jurídicas de direito público interno (União, Estados, Distrito Federal e Municípios) e de suas respectivas entidades autárquicas. Sem maior detalhamento, basta citar, entre outros consagrados autores de obras gerais, VALMIR PONTES, HELY LOPES MEIRELLES, CELSO ANTÔNIO BANDEIRA DE MELLO, LÚCIA VALLE FIGUEIREDO, DIÓGENES GASPARINI, MARIA SYLVIA ZANELLA DI PIETRO, ODETE MEDAUAR, DIOGO DE FIGUEIREDO MOREIRA NETO, e JOSÉ DOS SANTOS CARVALHO FILHO. Todos eles entendem que os bens públicos integram o patrimônio de alguma dessas mencionadas entidades dotadas de personalidade jurídica de direito público.

A jurisprudência tem uniformemente determinado o pagamento de indenização pela desapropriação de bens públicos, inclusive bens públicos de uso comum, como praças e vias públicas, conforme já por diversas vezes ocorreu quando da inundação de áreas urbanas em decorrência da construção de barragens. Não há porque dispensar, de maneira total e absoluta, o direito à indenização quando se tratar da constituição de servidão administrativa, pois, de qualquer forma, o direito de propriedade será sacrificado, ainda que parcialmente.

Com muito maior razão, não há como sustentar que a cessão voluntária de seus bens, ou do uso deles, por parte do Município, tenha que ser necessariamente gratuita.

O Código Civil, no art. 65, expressamente reconhece e afirma o domínio das entidades públicas sobre os respectivos bens. No art. 66, faz uma classificação quanto ao uso que deles se faça, sem que isso aniquile o domínio. $E$ no art. 68 deixa bem claro que o uso deles (de quaisquer deles, inclusive os de uso comum) pode ser gratuito ou oneroso. Realmente, não há como contestar a possibilidade de que o proprietário público estabeleça um pagamento pelo uso de seus bens por outras pessoas, físicas ou jurídicas, públicas ou privadas. Se assim não fosse, a simples cobrança de pedágio pelo uso de rodovia seria inconstitucional.

Com muitíssimo maior razão, é perfeitamente viável a cobrança de um preço público pelo uso especial de um bem público.

DIOGO FREITAS DO AMARAL, em sua notável monografia sobre "A utilização do domínio público pelos particulares” (Editora Juriscredi, São Paulo, 1972, pág. 217) chega a afirmar que o uso especial deve ser sempre remunerado:

"O fundamento deste dever de pagar uma quantia em dinheiro como retribuição do direito à utilização do domínio público é simples de entender e não se afasta, no essencial, daquele que alicerça idêntica obrigação a propósito dos usos comuns extraordinários. A sua justificação encontra-se luminosamente condensada nas palavras em que Jèze, sublinhando que o particular no uso privativo não usa a coisa como todos os outros mas para seu proveito pessoal, esclarece: seria injusto que de uma utilização privativa de certa coisa pública, construída e conservada com o 
dinheiro de todos os contribuintes, uma pessoa só extraísse gratuitamente vantagens exclusivas".

Essa situação não se altera absolutamente quando o uso especial é feito por uma empresa privada exploradora de serviço público. Nem mesmo haveria de ser gratuito se o serviço público fosse operado diretamente por uma pessoa jurídica de direito público diferente daquela titular do domínio, pois os patrimônios públicos são diferentes, afetando diferentemente diferentes contribuintes.

Preços públicos não se confunde absolutamente com tributos, conforme expõe, com sua insuperável clareza, o saudoso HELY LOPES MEIRELLES:

"Os preços - diversamente dos tributos - são remunerações facultativas e negociais, resultantes da aquisição de bens ou da utilização de serviços da Administração, ou de seus delegados, ou mesmo de particulares, em transações voluntárias com o Poder Público ou com pessoas de personalidade privada. Daí por que os preços tanto podem ser estabelecidos e cobrados pela Administração Pública, como por qualquer particular que aliene ou permita a utilização de seus bens ou serviços, mediante uma contraprestação em dinheiro, fixada ou ajustada negocialmente com o interessado no bem ou no serviço. Estes preços não dependem de lei para sua cobrança e podem resultar tanto de uma fixação unilateral de quem o cobra (preço público ou tarifa), como pode ser ajustado entre o Poder Público e o particular, conciliando os respectivos interesses (preço semiprivado), como pode ser discutido e acertado entre particulares em livre concorrência (preço privado). Os preços, quaisquer que sejam as suas espécies, nada têm que ver com os tributos. São categorias econômicas inteiramente diferentes e regidas por normas diversas".

HELY LOPES MEIRELLES, "Estudos e Pareceres de Direito Público", RT, São Paulo, vol. II, 1977, pág. 513

Portanto, não faz qualquer sentido a invocação do disposto no acima transcrito $\S 3^{\circ}$, do art. 155, da Constituição Federal, que se refere apenas e tão somente a tributos, como fundamento da impossibilidade da cobrança de preços públicos.

\section{IX - Conclusões}

Diante do que foi acima exposto, resta apenas sumariar, de maneira objetiva e sintética, algumas conclusões.

Estados e Municípios, bem como suas respectivas entidades autárquicas, podem cobrar um preço público pelo uso de seus imóveis, compreendendo o solo, o subsolo e o espaço aéreo. Delegatários de serviços públicos somente poderão cobrar se autorizados, expressa ou implicitamente, pelo delegante. Não havendo entendimento quanto às condições do uso, especialmente quanto aos valores de pagamento, poderse-á instituir servidão administrativa.

Havendo entendimento, concordando a empresa concessionária do serviço telefônico com os valores fixados pelo proprietário do bem público sobre o qual serão colocadas as instalações, dutos e fiação, o pagamento terá a natureza jurídica de preço público. Não havendo entendimento, havendo necessidade de instituir servidão administrativa, o pagamento estipulado pelo juiz ou acordado pelas partes terá a natureza jurídica de indenização. 
No caso do uso consentido, viabilizado por meio de concessão, permissão ou cessão de uso, deve ser observado o disposto na Lei Orgânica do Município ou na Constituição Estadual, quanto à necessidade ou não de concordância do respectivo Poder Legislativo. Normalmente, na maioria dos casos, os preços públicos são fixados por Decreto do Chefe do Executivo. Em se tratando de imóvel sob a posse de delegatário de serviço público, estando ele autorizado a ceder o uso a terceiros, o valor será fixado por contrato celebrado entre as empresas envolvidas.

Porém, nem as entidades públicas, nem as empresas delegatárias de serviço público podem, licitamente, agir com a desenvoltura de empresas imobiliárias, visando a obtenção de lucro. O pagamento a ser efetuado sempre deverá ter caráter indenizatório. É lícito cobrar, será lícita a receita obtida, desde que não sejam fixados valores exorbitantes, que não guardem uma certa relação com os incômodos ou danos causados pela uso de imóveis de seu domínio ou sob sua posse. Cabe registrar que, caso as pretensões sejam exorbitantes, o caminho a ser seguido deverá ser o da instituição de servidão administrativa.

Preços sempre dependem da concordância das partes envolvidas, que devem procurar valores razoáveis, que possam ser aceitos por ambas. Se o valor pretendido for inaceitável, restará o caminho da instituição de servidão administrativa, na qual o valor da indenização será fixado segundo o prudente critério do juiz. Em qualquer dessas situações, o valor justo sempre dependerá das circunstâncias específicas do caso concreto.

Finalmente, cabe lembrar que é inerente à concessão que o concessionário se disponha a prestar o serviço por sua conta e risco, tendo assegurado o direito à manutenção do equilíbrio econômico-financeiro estabelecido no momento e nos termos da outorga, mas arcando com eventuais prejuízos decorrentes de sua imprevidência, incúria ou inaptidão para explorar o serviço. Sempre será necessário verificar se o pagamento pelo uso de imóveis alheios estava ou não compreendido na equação inicialmente estabelecida. Podendo demostrar que tais pagamentos não estavam previstos e eram imprevisíveis, haverá necessidade de recomposição do equilíbrio contratual. A recomposição do equilíbrio deverá ser feita por aditamento contratual de maneira a compensar (por meio de aumento da receita ou redução das despesas) os custos adicionais. Caso haja discordância por parte do concedente, será necessário recorrer às vias judiciais para fazer valer o direito à manutenção do equilíbrio econômico-financeiro do contrato. 